\title{
External Factors Affecting EFL Self-Concepts of Students in Two Drama Clubs
}

\author{
Arifah Mardiningrum \\ Universitas Muhammadiyah Yogyakarta, Yogyakarta, Indonesia \\ Email: arifahmardiningrum@umy.ac.id
}

Submitted: 07/12/2019

Revised: 18/01/2020

Accepted: 24/01/2020

E-ISSN : $2579-4574$

P-ISSN : 2549-7359

\begin{abstract}
The study focused on the external factors inside the drama clubs affecting the EFL self-concept. The current study used a Comparative Case Study (CCS) design to compare the EFL self-concepts in two drama clubs through six participants. The study was a qualitative study, and the data were collected through interviews. The interviews were transcribed, coded, and analyzed by presenting the finding per drama club and then comparing between the two. The external factors affecting the EFL self-concept in Drama Club 1 were comparison to peers' English skills, people perceived as more competent in English, feedbacks from senior members and lecturer(s), play rehearsals, and on-stage performances. Meanwhile, the external factors in Drama Club 2 were preparation, feedback from peers and/or seniors, play-script, on-stage performances, feedback from a lecturer, and audiences' identity. Comparatively, the factors found hold some similarities in that significant others, their feedbacks, and the activities prior to and during the play had certain roles in affecting the participants' self-concepts. Meanwhile, the two clubs differ in the number of specific activities and the attitude that resulted from the presence and absence of a teacher figure.
\end{abstract}

Keywords: Drama in Education, Academic Self-Concept, EFL Self-Concept, External Factors

https://ojs.unm.ac.id/eralingua

This work is licensed under a Creative Commons Attribution-NonCommercial 4.0 International License. 


\section{INTRODUCTION}

Using drama in foreign language teaching and learning is not a new phenomenon. There has been a myriad of studies investigating whether the art of playing a role can be beneficial for learners. These studies have arrived in some conclusion such as, in the field of English as a Foreign Language (EFL), drama has been found to support the development of speaking (Sirisrimangkorn \& Suwanthep, 2012) and writing (Erdogan, 2012). Drama also supports the development of creative skills (Özdemir \& Çakmak, 2008), motivation and selfesteem (Sirisrimangkorn \& Suwanthep, 2012). However, these studies investigated the application of drama in EFL classrooms without involving public audience. In addition, drama performed in English was also still rare in for instance, Indonesia, where English is a foreign language. In Yogyakarta particularly, of many English departments, only few have a drama club which performs drama plays in English. This study aimed to investigate two of them.

The current study, in general, aimed at analyzing how drama clubs can be a place that supports English learning, be it not directly. More specifically, this study focused on one of the aspects that determines individual differences in a foreign language learner - self-concept. Many attempts to study the role of self-concept in education were conducted (see Badgujar \& Madnawat, 2017; Chen, X., \& Xu, 2015; Mardiningrum, 2019; Mardiningrum, 2017; Modecki, Blomfield, \& Barber, 2018; Marsh et al., 2019; Mercer, 2011a; Mercer, 2011b). However, studying self-concept bears some challenges. Shavelson, Hubner, and Stanton (1976) argued that the challenges of studying self-concept stem from the variety of ways to define its construct. In nature, self-concept can be explicitly stated as in a reflective manner and can also be implicitly inferred from a person's statements (Mercer, 2011a). It has, for example, been considered as having blur distinction from another term, such as self-efficacy (Marsh et al. 2019).

Shavelson et al. (1976) stated that in general, self-concept is a person's perception about himself, which is formed through his experiences with the environment. In addition, Shavelson et al. mentioned some characteristics that become the feature of self-concept. Self-concept is said to be "organized, multifaceted, hierarchical, stable, developmental, evaluative, and differentiable" ( $p$. 411). The way a person perceives himself is usually the reflection of a particular culture. This shows that self-concept is organized. Being multifaceted means that self-concept has many categories attached to it. The categories might be hierarchical. One self-concept might be divided into several ones. Concerning stability, general self-concept is usually more stable than a more specific selfconcept. It can be said that self-concept is stable in a short period of time (Shavelson \& Bolus, 1981). Further, Shavelson et al. (1976) stated that self-concept is developmental in a way that a child usually does not separate himself from his environment, but as he grows, he starts to separate himself and makes his own category. Thus, his self-concept becomes more complex and multifaceted. Selfconcept is also evaluative in a way that an individual always evaluates himself in different situations. The evaluation might be based on the standard, his own ideal, significant others, etc. Finally, self-concept is considered as differentiable from other 
similar constructs, such as behavior. With its dynamic and complex nature, Mercer (2011b) argued that a simple cause-effect model cannot capture its growth; however, when seen as a whole system, self-concept shows certain stability, even though its components might change over time.

One of the characteristics of self-concept is its multifaceted quality. General self-concept is usually divided into two facets - academic and non-academic selfconcept (Shavelson et al., 1976). The current study focused on the first one. Academic self-concept is a person's self-concept that is formed specifically toward academic domain (Bong \& Skaalvik, 2003). Further, Bong and Skaalvik concluded from various sources that academic self-concept appeared in an achievement situation. Strein (as cited in Wang, 2013) added that academic self-concept can be descriptive (eg., I like English) and evaluative (eg., I'm good at English), as well as emphasizes on educational competence rather than attitude.

Among many facets of academic self-concept, Mercer (2011a) used the term Foreign Language Learning (FLL) self-concept. Mercer (2011a) defined it as an "individual's self-descriptions of competence and evaluative feelings about themselves as a Foreign Language (FL) learner" (p. 14). Under this definition, the term English as a Foreign Language (EFL) self-concept in the current study was used. Additionally, the discussion in the current study is viewed from the point of view of academic self-concept as a means of understanding the more specific domain, namely, EFL self-concept.

In its development, self-concept is influenced by frames of references. These are the standards to measure a person's achievement (Skaalvik, 1997, as cited in Bong \& Skaalvik, 2003). There are two types of frames of reference; internal and external. Internal frames of reference are factors primary lie within oneself, where a person compares his/her achievement in one subject to his/hers in another subject, while external frames of reference are the ones coming from the outside of that individual, where a person compares his/her achievement to others' (Marsh et al., 2019; Mercer, 2011a). The current study focused on the later one. E. M. Skaalvik and S. Skaalvik (2002) called them external comparison, referring to a learner's comparison of own perceived achievement to others' perceived achievement. More broadly, relating to the foci of previous studies, Mercer (2011a) used the term to refer to any external factor influencing EFL self-concepts. Since the current study aimed at investigating any external factors, not only on specific frame of reference, the term 'external factors' are used.

Social comparison or comparison to others become one of the most common factors that influence academic self-concept. This comparison is usually done to peers (Mercer, 2011a; Möller, Retelsdorf, Köller, \& Marsh, 2011; E. M. Skaalvik \& S. Skaalvik, 2002). Students will compare their achievements to the ones of their classmates or peers (Möller et al., 2011) or to university students in general (Mercer, 2011a). Möller et al. gave the example that if the achievement of the students is higher than classmates, then their academic self-concept is also likely higher. E. M. Skaalvik and S. Skaalvik (2002) proposed five sources of information that students use to compare themselves to others. The sources are "(a) direct observation of achievement, (b) teachers' responses and comments in the 
classroom, (c) responses from classmates, (d) responses from others outside the classroom, and (e) grades" (p. 237). Social comparison is likely to be done to peers that are considered as similar or at the same level; however, special cases showed that the phenomenon can differ (Mercer, 2011a). Mercer found in her study that students at times also compared themselves to people; for example, family members that they considered as relevant to be compared in the context of the discussion.

Another common factor that influences academic self-concept is the presence of significant others. Here, their role is not as someone to be compared to as the previous one. The nature of the relationship between students and these significant others is the one that results in a critical event that helps forming the students' self-concept (Mercer, 2011a). The significant others that may give influence are teachers, parents, and peers (Mercer, 2011a). In relation to this, Kim and Sax (2014) found in their study that certain types of interaction between students and faculties played a part in the academic self-concept formation. They also found that students of differing majors have differing academic self-concept as a result of the form of contact with their professors. Meanwhile, the result of a study to US (domestic) college students and international students by Curtin, Stewart, and Ostrove (2013) corroborates to this. The study found that for both domestic and international doctoral students, the support from advisors was highly correlated to the students' academic self-concept. Conclusively, the studies have shown that significant others have greater influence on students' academic selfconcept in a variety of ways.

Significant others are not only influential in nature, but their feedbacks can also affect a student's academic self-concept. As mentioned previously, teachers' comments can be one of the sources of information for students to compare themselves to their peers (E. M. Skaalvik \& S. Skaalvik, 2002). However, teacher's feedback to the students, is also found to be influential without being the source of comparison. It is interesting that Wang (2013) found a significant correlation between self-evaluation and others-evaluation. This means that how significant others perceive a student is strongly correlated to how the student perceives him/herself. This is an indirect implication that what significant others think is important for a person's self-concept. In a case study on EFL self-concept, Mercer (2011a) found significant others "ranged from family members, to boyfriends/girlfriends, penfriends," depending on who is considered as affecting the students' EFL self-concept (p. 133). Teachers seem to be the one most dominant (Mercer, 2011a). What teachers expect of a student may influence the way they give feedbacks to the students (Chen, Thompson, Kromrey, \& Chang, 2011). Chen et al., in their study to Taiwanese elementary students, found that there is a strong correlation between positive academic feedback and positive academic selfconcept. Positive academic feedback here was based on how the students perceived the feedbacks given to them.

As an extracurricular activity (EA), drama club resembles classrooms in many ways (Covay \& Carbonaro, 2010). As Covay and Carbonaro argued, EA can be a place where the members learn similar values as in a more academic context such as 
classroom. Demanding its members to do an art performance, drama clubs teach its members to present themselves in public where they will be judged by other people (audience). Covay and Carbonaro added that as an EA, drama club also becomes a place to learn social interactions. The members can learn from interacting with the authority such as play directors or drama coach. They can also build a sense of competition with peers or fellow members and mimic the behavior of more prominent figures such as members considered as seniors. Lastly, Covay and Carbonaro, concluding from past studies, argued that an EA can promote noncognitive ability, such as integrity and hard work, which has been found to be related to higher achievement. With this resemblance to classroom condition, academic self-concept such as EFL self-concept might emerge. However, studies on academic self-concept in the context that is not entirely academic such as a public drama performance or a drama club has been scarcely done. It might be due to rather non-distinct connection between the two. This is the gap that this study tried to fulfil.

\section{RESEARCH METHOD}

This study is a qualitative Comparative Case Study (CCS). CCS is more focused on what Maxwell called as "process orientation" (as cited by Bartlett \& Vavrus, 2017 , p. 8). This means that a case is a process that will explain how people, events, places connect to each other and how the connection happens. In line with this, the current study took EFL self-concept in two drama clubs as the case experienced by each individual involved. What emerging from the data were used to understand the connection between factors in the drama clubs and the members' self-concept by exploring its members' experiences.

The current study used interviews and field notes as data collection instrument. The interviews were conducted to the six participants and two individuals considered as the supervisor and the senior member. For the participants, interviews were conducted twice. The first interview was a structured interview (Gay, Mills, \& Airasian, 2009). After the first interview was transcribed, some memos were written to mark parts that needed clarification or further information. Therefore, some parts of the interviews were more individualized. The second interview was unstructured and informal, which, as Gay et al. stated, was used to understand more participant's experience to gather more complex or personal information. Three participants did face-to-face interview, and three chose an interview by telephone because they were in a different place not conveniently reachable to the researchers.

To gain more trustworthiness, a member-checking was done by showing the written transcripts of the first interview to the participants. One participant did a little revision to the transcript and one made a request concerning the identity of a person mentioned in the interview. All confirmed that the transcripts were valid. Data were analyzed using data layout (printed transcripts and field notes), precoding (highlighting and preliminary memoing), preliminary jottings (analytic memos), and relating to theories and questions the study aimed to answer (Saldaña, 2016). 
Six participants were involved in the study chosen based on two informants. The participants were all in their early twenties, two of them are females and four of them are males. All are presented in pseudonyms. Participants were chosen because they were considered as suitable to understand the case taking place in the context of the study. They were students in two English Education Departments (EED) in Yogyakarta, Indonesia, who were also active members of the English drama club in each department and had performed in English plays for at least twice. Participants' pseudonyms were Novian, Vanda, Iwan (Drama Club 1), and Grace, Kenny, and Sean (Drama Club 2). In the current study, Drama Club 1 was called Spectare and Drama Club 2 was called Theatron (both are pseudonyms).

\section{RESULT AND DISCUSSION}

The finding of the study is presented in a way that showcases the factors that emerged from participants' interviews and field notes and what EFL selfconcept emerged as a result of these references. The findings are presented per case or per drama club.

\section{Case 1: EFL Self-concept in Spectare}

Context. Spectare is an English drama club founded in 2015 under an EED of a private Islamic university in Yogyakarta, Indonesia. The plays were all in the form of musicals. In the beginning, the plays were all recorded and performed on stage by lip-syncing. However, one play had been done live. All plays were English adaptations of Indonesian folklores. The musicals were between 15 to 25 minutes and were all performed as a part of a bigger program. The shows were all free of charge. All actors were EED students, but few musicians were sometimes of students of different majors. Actors to play the roles were usually chosen by the supervisor through his prior knowledge of the actors inside and outside the drama club (e.g., classrooms). Rehearsals were done by reading the script, focusing on intonation, pronunciation, articulation, and emotions. After the supervisor saw that the actors were ready, the recording was done. On stage rehearsal was done after the recording was finished. From this step, the focus was more on the visuals on the stage.

External Factors Influencing the EFL Self-concept in Spectare. The current study found five factors that appeared to affect the EFL self-concept of the three participants in Spectare. The factors are comparison to peers' English skills, people perceived as more competent in English, feedbacks from senior members and lecturer(s), play rehearsals, and on-stage performances. The factors, at certain point, might overlap with each other. The decision to put one phenomenon into one category is based on its stronger tendency to particular factors.

Comparison to peers' English ability. All three participants stated that they, at times, compared themselves to their peers in the club. The EFL self-concept tended to be positive. They felt that their English mastery was better than their fellow club members on certain aspects.

Novian, who since the beginning, already showed confidence about his English ability, seemed to be more convinced when he saw his friends' performance, as the data extract below shows: 
N: May be, when I saw my friends, for example, when they were speaking, I [believe] I could do better. For example, when I saw other actors, like Putra, talked [in English], I was thinking that I could do it better.

In the excerpt above, the comparison to peer's ability becomes more of a confirmation that his English was good. Vanda and Iwan shared similar experience to Novian, but they compared her ability in English based on the number of times she and her friends were corrected by the senior members in the drama club. In addition to this, Iwan made the comparison to his peers from the interaction that he had during rehearsals where he seemed to be taken as a more capable person by his peers.

All three participants compared themselves to their peers based on their experience during rehearsals from watching their friends' struggle to meet the expected performance. However, Novian also built his positive self-concept because he was the only one chosen directly by the supervisor as a leading actor since his first play.

People perceived as more competent in English. All three participants seemed to hold a strong belief since the beginning that some individuals were more competent than them and they would always trust these individuals' judgement. This is implied in one of the excerpts from Novian's interview:

$\mathrm{N}$ : I did [suggest a change in the script], but I was still afraid. I had only asked,

"What if I add something like this, Sir?" He said, "Oh, that's good, but I prefer this, so it will be like this, and this". Well, I just asked, but Mr. Prabu knows more.

In another interview, Novian also mentioned some senior members perceived as more competent in English. Novian stated that he struggled with his vocabulary mastery and often had to switch between English and Indonesian when speaking to his seniors. A similar view was shared by Iwan and Vanda, who both believed their seniors' English was better than theirs.

Feedbacks from senior members and lecturer(s). In addition to their presence, the supervisor's and seniors' feedback to the participants' performance also seems to affect the participants' EFL self-concept.

Novian has shown his confidence on his English. The absence of the supervisor's corrective feedback on his language seemed to strengthen his positive self-concept. Further, Novian also mentioned that the comments from senior members were mostly not about his English performance. On the contrary, Vanda declared that she received feedbacks on her English. However, she seemed to take it as minor corrections, which did not immediately cause her to feel anything bad.

$\mathrm{V}$ : If I look at it from the comments given to me, my pronunciation is good. They just said that I need to have more vocabulary mastery.

As implied in the above excerpt, Vanda seemed to lightly accept feedbacks or comments from her seniors and her supervisor. The feedbacks from seniors and the supervisor seemed to be taken lightly and gratefully as a normal part of learning. Similarly, Iwan said that he was pretty good at receiving feedbacks since he always understood what to do after a feedback and complied to what was suggested. 
Play rehearsals. This category refers to the experiences during rehearsal, which was not related to other individuals in the play or the drama club. The reported self-concept emerged from two participants.

Telling what it took to really understand a play script and the whole story of the play, Iwan described his process:

l: $\quad$ Sometimes, it was difficult to understand the content of a story in the beginning. It's mostly because I did not know some of the vocabulary. But then, I sometimes asked the seniors again and again, "Brother, do you know what this means?" [They replied], "Oh, it means this. So, from those words, we can see how the plot is." I did need to read the text, the script, multiple times to understand it. Bit by bit, until I finally comprehended the plot of the story. How the story goes.

Iwan's story of his efforts of understanding a script shows he made efforts based on what he needed. Further, he mentioned that the success of the show was partly because of that efforts.

Similarly, Vanda said that she felt that her speaking skill improved a lot. However, by 'speaking', she actually meant that her vocabulary mastery improved, and based on her story, the experiences of reading the script for multiple times helped her in this improvement.

On-Stage Performances. The products of Spectare are English drama plays. However, the audience does not always consist of people who speak or understand English since English is a foreign language in Indonesia. Therefore, it is quite expected that the participants' experience on stage become one of the themes emerging from the interviews. However, only Novian shared a story of a process relating to his EFL self-concept on stage. This relates to the fact that he was the only among three that mentioned improvisation in his performance. When asked about how he felt about his improvisation, he said:

N: Well, I felt more ..., when I was behind the stage, I was like, "Gosh, I forgot!" I felt bad, but the seniors said, "It's okay. No one heard it after all because of the back sound."

In the extract above, it can be seen that Novian thought of improvisation as part of his failure in performing based on what had been rehearsed and that resulted in his disappointment. In addition, in another interview, he also believed that the reason for this to happen was the lack of his confidence, which made him nervous and forgot his lines. However, in another part of the interview, Novian seemed to show positive self-concept in his ability in improvising dialogues. He believed that he was not a good memorizer of a long dialogue. Although it sounds like a negative self-concept, it shows that he was confident in his ability in changing words impromptu.

\section{Case 2: EFL Self-concept in Theatron}

Context. Theatron is an English drama club initiated in 1999 by a group of students of an EED in a state university in Yogyakarta, Indonesia. There was a regular play ( 1.5 to 2 hours) each year performed as the part of a bigger program. Additional short plays (half an hour show) were performed several times. In its early years, the shows were all in English and the mix of English, Indonesian, and 
Javanese. However, in the recent years, some shows were performed entirely in Indonesian. English plays were adaptations or original scripts of English classics and students' self-written plays. The mix plays were adapted from Indonesian folklores. The Indonesian plays were adapted from short movies. The club was entirely run by students. Many senior members were still actively involved during rehearsals and the stage performances. Prior to every show, rehearsals were done rigorously. It began with a casting for actors and script reading, where the script was scrutinized, discussed, and when necessary, revised. Revision was based on feedbacks from everyone involved. After that, each actor would individually do research and practiced their role. The next step was on-stage rehearsals. Directors had a prominent authority. The focus of feedbacks during rehearsals were more on the acting quality of the actors. Language use and accuracy were left to actors to work on. The big plays were usually sold with affordable tickets.

External Factors Influencing the EFL Self-concept in Theatron. The terms used in this second case are slightly different from the one in Spectare, although in details, they hold similarities. The emerging factors to affect the EFL self-concept of the participants in Theatron are preparation, feedback from peers and/or seniors, play-script, on-stage performances, feedback from a lecturer, and audience identity.

Preparation. Preparation in this context includes script reading, script analysis, self-preparation, and rehearsals. The preparation was quite rigorous since all English plays were set in different countries and different eras. Therefore, most of the plays were new things for each participant.

Grace, who had always played the main role, said she never really received constructive feedbacks related to her English. She said that the comments were always positive, but they never satisfied her. The constant positive feedbacks made her question herself. She reasoned that she needed a figure, like a lecturer, to make her feel completely good about her English because doing it by herself did not really give her assurance of the quality of her English, and thus did not really support her language improvement.

Additionally, Grace informed that she would then look at different sources to make sure her understanding of the text is on point. Another reason for her doubt of her English was the director him/herself. She informed that there had been a silent consent among the drama club members which person is a qualified director. It can be summed up then that she would trust certain directors, but not the other ones considered not so competent.

Self-doubt was also felt by Kenny, who had only played twice as an actor. Since the beginning, he said that his forte was in music and not acting or performing in public. Kenny informed that he always did rigorous research on his role before rehearsal so that he could use suitable linguistic feature, such as accent. About whether his performance was successful, he said:

K: I think so because, well, it was a process of when I learned myself. I knew the standard. I set the standard, and I met that standard. So, I successfully acted it out.

The excerpt shows that Kenny believed that being well prepared was the key to his success in performing what he considered as Italian English accent (the 
accent he needed to perform). This is a positive self-concept from a person who admitted that he was not keen on English pronunciation.

Meanwhile, Sean, who had experienced being a writer and director, showed confidence that he had no issue in understanding what the right accent is from careful research and observations. This positive self-concept also seemed to emerge from the belief that he had done a needed preparation.

Feedback from peers and/or seniors. Since there was no supervisor, everyone seemed to be considered as equal in terms of English mastery because everyone was a student or a former student in Theatron. Two participants showed how feedbacks from other members meant for them. Grace shared her view:

G: In terms of pronunciation, thank God, I am not accented. That's what my friends said. That's why when they looked for a leading actor, they liked to choose me.

Grace showed her positive perception on her ability in pronouncing words and her lack of accent. As a note, 'accented' here refers to the accent of certain vernacular in Indonesia. In Theatron, accent appears to be taken as an important part of the play since each play has a different setting that might explain why not being accented is considered as good because this will make actors versatile to do different accents.

Kenny, on the contrary, showed lack of confidence in his spoken English. He said he received feedbacks from his friends that his utterances were accented and that he did not put the right stresses to his words. The feedback made him see that his English was mediocre. Kenny believed his friends' feedbacks because they were more competent and more experienced than him. Thus, his perception on who gave feedbacks also matters.

Play-script. Since the plays were created by students and had diverse settings, the nature of the script affected the participants' EFL self-concept, especially because two of them were script writers and play directors once.

Sometimes lines in a script needed to be revised and actors had the right to do that. This, sometimes, made Grace believed that her grammar knowledge was not good enough because even when she already revised her lines, she said that she still found something wrong. However, she still preferred scripts in English to the one in Indonesian because of the comfort it offers. She said that English was more comfortable when having to use harsh expressions and people rarely commented on the language use.

Meanwhile, Kenny shared that when he became a scriptwriter, his friends said that his English was too textual. Kenny indicated that for him and his friends, a script should show less formality - like a real conversation. Later he said that consequently, some lines in his script were changed based on the discussions with his peers. He had no objection because it would help his friends, but "felt inferior" and felt that his "language was mediocre". He said that after what happened to his script, he took more time to learn spoken English through videos, talks, and presentations available online.

Unlike Kenny, Sean's reaction to people's comment on his script did not immediately make him feel inferior. This might be due to the different sense that the comments imply: 
R: In the rehearsal, how did your friends respond to your script?

S: $\quad$ Let's see. They said it was difficult.

R: They said that?

S: Yes. Because I used idioms.

...

R: Idioms are difficult for your friends?

S: (lough)

R: How did you react when they did not understand your script?

S: Well, I would say, "Well, this is new knowledge. Don't complain."

The excerpts show that Sean had a strong perception of the quality of his script and when others struggled, it was their job to try to understand it as actors. Previously, he also explained that his play script was a satire, and that he was good at that genre. He appeared to unintentionally position himself as the more competent person than his friends. Despite this confidence, as an actor, Sean also experienced trouble in understanding a classic English play because the English used was an old English.

On-stage performances. Unpredictable thing happened to Grace when she performed for the first time. She had to improvise with her role. However, she was dumbfounded because of her nerve. She believed that her English was not so good, but she was proud to be able to improvise when she was only a freshman at that time. After she became a more seasoned actor, her issue became more on her accent. Although previously, she perceived that she had no accent from what her friends said, when she watched her recorded performance on stage, she shared:

$\mathrm{G:} \quad$ The intonation was really bad. I still looked like reading. It was like [reading]. In terms of my acting, I did it like I had completely understood my [character], and I cried genuinely. But why did I [sound] like that?

Grace said that her disappointment was caused by her inconsistent accent. She sometimes switched accents in one play and said that it was not alright. Similar disappointment towards the sound of accent was also shared by Kenny.

Different from his two peers, Sean had always been the one sounding confident. He stated that he felt that his performance was a total success, including his language performance because he felt comfortable entirely with everything he did on stage. Further he added that this feeling more often existed than not, and it was the result of his well-preparedness.

Feedback from a lecturer. Although having no lecturer as the supervisor, some lecturers might attend Theatron's plays as audience and gave feedbacks after the shows. One feedback appeared to be affecting Sean's EFL self-concept and might explain his confidence shown throughout the interviews. He shared:

S: $\quad .$. Kenny and Hendra were my actors at that time. And Hendra was a literature student. So, he was asked by Mrs. Wanda, "Who wrote [the play]?" "Sean, Mam. He's an English Education student." [She said], "How come you guys lost to an English Education student?" There, I felt proud.

Later, Sean explained that Mrs. Wanda was the dean of the faculty of language and literature and a lecturer in the English literature department. This also likely to influence the amount of pride that Sean felt with her compliment. 
Audience identity. One of the things highlighted by one participant was that Theatron had helped him to be more confident. Sean's source of confidence lays here:

S: My performance, my language, because the audience was also the people who understood English. Let's not make any mistake, so we will not be criticized.

Indirectly, Sean showed his belief that his English was good, and that the reason to his belief is that when he received compliment from the audience, he received it from eligible people who knew what they were looking for from a performance.

\section{Comparing the two Cases}

The experiences of six participants in two drama clubs show some similarities and differences and depict the logic of how some factors inside the drama club affected the participants' EFL self-concept. In summary, the factors found in Spectare are comparison to peers' English skills, people perceived as more competent in English, feedbacks from senior members and lecturer(s), play rehearsals, and on-stage performances. Meanwhile, the factors found in Theatron are preparation, feedback from peers and/or seniors, play-script, on-stage performances, feedback from a lecturer, and audience identity.

Similarities. The two clubs shared similar features in nature. Both belong to an English Education Departments and both performed plays for public audience on stage, and the members were students who study English formally. The process to the performances were also similar. Therefore, the nature of how the factors inside the drama clubs affecting the participants' EFL self-concept were also similar.

Prominent figure. The nature of a drama play itself already holds the expectation that there would be a prominent figure that the members respect. $A$ play usually needs a director that controls and leads the play who is usually given full authority. Thus, it is not surprising that the presence of significant others, which in these two drama clubs are the supervisor or lecturer, senior members, and peers, seems to play a part in how the participants perceived themselves and their English. In Spectare, this figure is the lecturer that was assigned to be the supervisor in the club. This corroborates to some studies which found that teachers (or lecturers/ professors) are the most prominent figures to influence a student's academic selfconcept (see Curtin et al., 2013; Mercer 2011a; Kim \& Sax, 2011). In addition, the lecturer also played a role as the director and the script writer of some plays, which means that his influence is unquestionable since the members of the club will always look up to him as has been shown throughout the interviews. Equally, senior members in Theatron and senior members in Spectare also became significant others that the participants looked up to. In Theatron, the seniors were considered as the more experienced one to hold a play and so they deserved to be listened to. Meanwhile, in Spectare, senior members considered as prominent are the ones that the participants saw as more capable in performing English skills such as in speaking. This also applies to peers, who were seen as more capable. This is in line to Mercer's (2011a) finding that peers can also be the factor to influence academic self-concept. Here, senior members and peers were seen more as role models. 
Feedbacks from significant others. Another similar factor in the drama clubs that affect the participants' academic self-concept is the feedbacks given by significant others. Again, the others here are the lecturer, senior members, and peers. It can be seen in the finding that from the six participants, Novian of Spectare and Sean of Theatron are the ones showing more confident in general. It can be seen throughout the interviews that other participants still held certain anxiety about what other said to them. It is interesting that both Novian and Sean were the one mentioning a specific appraisal from their lecturers that seemed to make them think they outperformed their peers and felt some type of validation of their skill. On different side, the other participants also mentioned some positive and negative self-concepts that resulted upon hearing feedbacks from their peers or senior members. This substantiates that others' evaluation might also denote selfevaluation (Wang, 2013) and confirms that feedback from teachers are central in affecting academic self-concept (Mercer, 2011a; Chen et al., 2011).

Varied experiences. The last similarity that can be drawn from both drama clubs is the varied experiences that the participants had in each club. The experiences were linked to the activities prior to the show and the on-stage performance. Most of the experiences happened during the rehearsal or preparation activities and a few happened on stage. This might be because preparation needs longer time and more intensive interaction among members than on stage performance that only lasted for minutes. As stated by Covay and Carbonaro (2010), drama club resembled classroom in a way that members learn social interaction with peers and authority (directors, senior members, lecturer) and imitate the behavior of the significant others in the club, which is what happened to the participants during the preparation of the plays.

Differences. Although in general, both drama clubs provided similar factors to influence the academic self-concept of their members, when observed in detail, they hold some differences.

Forms of independence. As mentioned previously in the finding, Theatron was independent in a way that it was not supervised by any prominent figure like a lecturer, as Spectare was. This means that prominent figure was naturally made by years of experiences and membership in the club. This also means that the members had to prepare and took care of many aspects of the play by themselves without the help of one authority. They were put in a situation where they needed to figure out, for example, what was the right pronunciation, the right accent to use, since everyone was considered equal in terms of English mastery. This results in more varied self-concepts and more influencing factors. As proposed by E. M. Skaalvik and S. Skaalvik (2002) that social comparisons take place from various sources of information.

Sources of comparison. One of the sources of social comparisons is "direct observation of achievement" (E. M. Skaalvik \& S. Skaalvik, 2002, p. 237). The more varied experiences (directing, writing the scripts, searching for the suitable accent, etc.) during the preparation of each play in Theatron gave the members the change to observe their achievement in different situations; for example, when they tried a certain accent in performing a dialect and realized that it did not impress their 
peers, self-concept about accents then emerged. The more activities of trials and errors in Theatron also gave more opportunity for social comparison, significant others and their feedbacks to emerge and gave influence on its members' certain self-concepts.

Absence of prominent figure. Lastly, the absence of a lecturer involvement in Theatron seems to result in a different attitude of its members from the ones of Spectare. Iwan of Spectare, for example, still focused on what his lecturer said about the play when he said that he felt so proud, which shows a positive selfconcept. This is similar to what Mercer (2011a) found in her study where she concluded that teachers had the most dominant influence on a learner's academic self-concept. Meanwhile, Theatron member like Sean, felt that his English was good because he received only positive feedbacks from the audience in general because he believed that the audience were people who also understand English well. This is an interesting finding, which might shed some light on what constitutes a prominent figure or significant others. There seem to be a replacement of an absent respected figure in the development of similar academic self-concept, which still needs further discussion in the future studies.

\section{CONCLUSION}

From the findings, some conclusions can be drawn. First, the way a drama club is organized affects the specific English self-concept of its members. More general EFL self-concept seems to be affected in a more complex way, which might involve the members' internal process or individual past experiences. Second, the presence of a prominent figure in the drama club is necessary to build certain confidence but can also hinder the development of self-concept that comes from internal process. This implies that a prominent figure is needed, but with limited interference to the members' learning process. Finally, positive self-concepts have been shown throughout the data. This implies that an English drama club is a good program that deserves to consider in any institution willing to improve its students' self-concept, which in the long run, will likely affect their achievement.

\section{REFERENCES}

Bartlett, L., \& Vavrus, F. (2017). Comparative case studies: An innovative approach. Nordic Journal of Comparative and International Education (NJCIE), 1(1), 5 - 17.

Badgujar, L. K., \& Madnawat, A. V. S. (2017). A comparative study of self-concept among college going students of Jaipur. Indian Journal of Health \& Wellbeing, 8(7), $594-597$.

Bong, M., \& Skaalvik, E. M. (2003). Academic self-concept and self-efficacy: How different are they really? Educational Psychology Review, 15(1), 1- 40.

Chen, X., \& Xu, H. (2015). Understanding interaction inside and outside the efl selfconcept system: A case study of Chinese learners in Junior High School. Chinese Journal of Applied Linguistics, 38(2), 133-149.

Chen, Y. H., Thompson, M. S., Kromrey, J. D., \& Chang, G. H. (2011). Relations of student perceptions of teacher oral feedback with teacher expectancies and student self-concept. The Journal of Experimental Education, 79(4), 452-477. 
Covay, E., \& Carbonaro, W. (2010). After the bell: Participation in extracurricular activities, classroom behavior, and academic achievement. Sociology of Education, 83(1), 20-45.

Curtin, N., Stewart, A. J., \& Ostrove, J. M. (2013). Fostering academic self-concept: Advisor support and sense of belonging among international and domestic graduate students. American Educational Research Journal, 50(1), 108-137.

Erdogan, T. (2013). The effect of creative drama method on pre-service classroom teachers' writing skills and attitudes towards writing. Australian Journal of Teacher Education, 38(1), $44-6$.

Gay, L. R., Mills, G. E., \& Airasian, P. W. (2009). Educational research: Competencies for analysis and applications, student value edition. Upper Saddle River, NJ: Merrill.

Kim, Y. K., \& Sax, L. J. (2014). The effects of student-faculty interaction on academic self-concept: Does academic major matter? Research in Higher Education, 55(8), 780-809.

Mardiningrum, A. (2019). EFL self-concept in an English drama club: A case study of two English language education department students. In A. Nurmandi, Y. Chen, N. A. b. Ismail, \& Z. Rafique (Eds.), Third International Conference on Sustainable Innovation 2019-Humanity, Education and Social Sciences (IcoSIHESS 2019) (pp. 15-21). Atlantis Press. Retrieved from https://www.atlantis-press.com/proceedings/icosihess-19/125919842

Mardiningrum, A. (2017). EFL Teachers' linguistic self-concept in a study abroad (SA) Program. Journal of Foreign Language Teaching \& Learning, 2(2), 27-37.

Marsh, H. W., Pekrun, R., Parker, P. D., Murayama, K., Guo, J., Dicke, T., \& Arens, A. K. (2019). The murky distinction between self-concept and self-efficacy: Beware of lurking jingle-jangle fallacies. Journal of Educational Psychology, 111(2), $331-353$.

Mercer, S. (2011a). Towards an understanding of language learner self-concept (Vol. 12). London: Springer Science \& Business Media.

Mercer, S. (2011b). Language learner self-concept: Complexity, continuity and change. System, 39(3), $335-346$.

Modecki, K. L., Blomfield Neira, C., \& Barber, B. L. (2018). Finding what fits: Breadth of participation at the transition to high school mitigates declines in selfconcept. Developmental psychology, 54(10), 1 - 41.

Möller, J., Retelsdorf, J., Köller, O., \& Marsh, H. W. (2011). The reciprocal internal/external frame of reference model: An integration of models of relations between academic achievement and self-concept. American Educational Research Journal, 48(6), 13151346.

Özdemir, S. M., \& Cakmak, A. (2008). The effect of drama education on prospective teachers' creativity. Online Submission, 1(1), 13-30.

Saldaña, J. (2016). The coding manual for qualitative researchers. Los Angeles: Sage.

Shavelson, R. J., \& Bolus, R. (1981). Self concept: The interplay of theory and methods. Journal of educational Psychology, 74(1), 1- 37. 
Shavelson, R. J., Hubner, J. J., \& Stanton, G. C. (1976). Self-concept: Validation of construct interpretations. Review of educational research, 46(3), $407-441$.

Sirisrimangkorn, L, \& Suwanthep, J, (2012). The effects of integrated drama-based role play and student teams achievement division (STAD) on students' speaking skills and affective involvement, Scenario, 2013(2), 37- 51.

Skaalvik, E. M., \& Skaalvik, S. (2002). Internal and external frames of reference for academic self-concept. Educational Psychologist, 37(4), $233-244$.

Wang, M. (2013). The study on the relationship between English self-concept and significant others. Theory and Practice in Language Studies, 3(8), 1406 - 1411. 